\title{
Choosing between service fees and budget funding to pay for local services: Empirical evidence from Spain *
}

\author{
GERMÀ Bel (Universitat de Barcelona) \& ANTONIO Miralles (Boston University) \\ Forthcoming in Government \& Policy
}

\begin{abstract}
:
In this paper we investigate how local governments finance public services, and their choice between budget funding and flat service fees. Based on a simple model of electoral competition we predict that the tax policy will be extreme (either progressive or conservative) only if both the voting majority's economic interests and the valence point to the same ideological side. If ideological and economic interests diverge, then the equilibrium policy will be a moderate one. From our empirical analysis, we find that progressive mayors in progressive constituencies use budget funding to a greater degree, whereas conservative mayors in conservative constituencies prefer flat service fees. When the political affiliation of the mayor and the ideological bias of the constituency diverge, more moderate policies are chosen. We find also that service-specific deficits are lower in cities with private production of solid waste service. Thus, policymakers may have used privatization as a means to reduce the political cost of increasing service-specific taxes.
\end{abstract}

JEL Codes: H20, H30, H71.

Keywords: Local government, Local public goods, Tax choice, Voting model.

* The Spanish Ministry of Education and Science (SEJ2006-04985) has financially supported the research for this paper. Germà Bel also acknowledges support from the Rafael del Pino Foundation. This paper has been presented in the 2005 Western Political Science Association Meeting, the 2005 Western Social Science Association Conference, and the 2005 Canadian Public Economic Group Conference. We thank Steve Coate, Kenneth Fernandez, Douglas J. McCready, Steeve Mongrain, Jason Snyder, several anonymous referees and the editor for useful comments and suggestions. 


\section{Choosing between service fees and budget funding to pay for local services: Empirical evidence from Spain}

\section{Introduction}

Public services can be funded from the budget or through service fees, and in many cases, funding is mixed, since fees often do not provide enough revenue to pay the full cost of the service. In most countries, local taxation relies heavily on real property values, as well as on other taxes that reflect tax-payer wealth or income. Service fees, in contrast, require the same payment whatever the user's wealth or income. Thus, budget funding tends to be associated with progressive taxation, while service fees are not. Within this framework, the choice between budget funding and service fees can be seen as a product of the ideological preferences of governments. Do progressive governments rely more on budget funding? Do conservative governments prefer flat fee services? This paper analyses these questions, by recognizing that the socio-economic preferences of voters will likely influence the choices made by government.

When service fees are not used, or they do not fully pay for the cost of the service, a servicespecific deficit emerges. The present paper deals with service-specific deficits at the municipal level. These are not proper deficits as they are covered by revenues earned in other ways by the municipality. Hence, we also consider the way in which public services are financed in a global zero-deficit setup, i.e. the types and shares of different taxes that are to be used. Political economics has been applied to taxation by, among others, Norstrand (1980), Hettich and Winer (1984, 1988), Blackley and DeBoer (1987), Biegeleisen and Sjoquist (1988), and Stine (1998). A particularly interesting paper is Hettich and Winer (1984), which postulates a political cost function depending on the share of each possible tax on total revenues. Politicians set tax shares to minimize political costs, in such a way that marginal costs coincide among the different shares. This idea is formally refined in Hettich and Winer (1988) to include administrative costs. 
They conclude that their approach is consistent with the evidence of some diversity in the types of taxable activities.

We take a similar approach, yet we analyze a particular local public service, and we hypothesize that political organizations aim not only to win elections, but also, having won, to implement their ideologically preferred policies. This is in line with literature (Wittman 1983; Calvert 1985, Alesina 1988, Dixit and Londregan 1998, Roemer 2001, Ortuño-Ortín 2002) that casts doubt on the classical paradigm that politicians care only about maintaining (or reaching) power. From our point of view, ideological identification via programmatic proposals that differ from the other party's proposals is necessary to the maintenance of cohesion within a political organization. Additionally, ideological considerations might simply enter the politician's utility function directly.

We postulate that the tax structure is the result of a balance between voters' preference for the local ruling party or mayor (the so-called valence) and voter's economic interests in relation to the tax structure. The latter depend on such socioeconomic variables as wealth distribution in a stronger way than do valences. When valence and social features push towards the same ideological pole, the ruling party implements its (ideologically) most preferred tax structure. When there is no such coincidence, the party favored by the valence can keep its position by adopting a moderate tax structure that departs from the party's (ideologically) most preferred policy.

Recent theoretical literature on valence issues has focused on extending previous work on one-dimensional decisions to multidimensional policy choices (Ansolabehere and Snyder, 2000) or multidimensional valences (Wittman, 2005). We propose a different extension to the onedimensional problem, namely the introduction of additional interests apart from winning office. We introduce the double dimensionality of the sociopolitical context (the socioeconomic interests plus valence factors) in explaining tax progressiveness. This double dimensionality constitutes our major contribution to this field.

The next section of this paper sets out the theoretical considerations and assumptions that drive us to state the main hypotheses. An empirical examination of the funding and delivery of 
solid waste collection and treatment services in a sample of Spanish municipalities is then used to test our hypothesis. ${ }^{1}$ We find that progressive mayors in progressive constituencies make more use of budget funding, whereas conservative mayors in conservative constituencies prefer flat service fees. However, when the mayor's political affiliation and the ideological stand of the constituency diverge, more moderate funding policies are chosen. Finally, we offer conclusions and a short appendix summarizing complementary information.

\section{Theoretical basis}

The theoretical model we develop here is intended to illustrate the main idea tested in this paper: tax policies are ideologically extreme if and only if both the non-economic and economic preferences of voters point towards the same type of policy. The reader should not expect a general political equilibrium (multidimensional) model. Instead, the model focuses on one kind of local policy (namely, taxation related to a specific public service), while taking the equilibrium in other policies as given.

To begin the construction of our model, we assume that a public service is to be provided by the government and that the resulting production of public good generates an extra utility $\mathrm{g}$ to one or more of the $\mathrm{N}$ citizens at some total cost $\mathrm{C}$

The public good is to be financed in part by a specific service fee, and in part from the general budget. The local government may decide some parameter $\lambda \in[0,1]$, which represents the percentage of service costs that are funded via general budget, or equivalently, the servicespecific deficit. This deficit cannot be maintained at a global level. The sum of local government current revenues may not be below the sum of all local government current expenditures. Those revenues come from the service fee and from a general local government tax scheme, which is

\footnotetext{
1 Empirical analysis of solid waste financing has received scarce attention in Economics Literature in Europe so far. The most outstanding works are those by Dijkgraaf and Gradus (e.g. 2004), which analyze unit-based pricing in the Netherlands. This pricing system does not exist in Spain for solid waste services. On the restructuring of local and municipal services see Bird and Slack (2007), Bel and Warner (2008) and Hebdon and Jalette (2008). Rodriguez-Pose and Sandall (2008) provide an analysis on general restructuring of government. See Lago-Peñas (2005) for the specific case of Spain.
} 
represented by a per-agent tax function $t(\cdot)$ that depends on voter's wealth $w_{i}$ (say, real estate value), where the subscript identifies the voter. We take for granted that the tax function $t(\cdot)$ is strictly increasing (and thus more progressive ${ }^{2}$ than the specific poll tax), that $t(0)=0$ and that its progressiveness cannot be changed by the local government.

The service deficit, $\lambda C$, must be financed by the rest of local government revenues. The specific poll tax returns an amount $(1-\lambda) C / N$ per citizen. If a specific deficit rate $\lambda$ is chosen, then the rest of local government revenues must be increased by a proportional rate $\mu$ such that $\mu \sum_{i=1}^{N} t\left(w_{i}\right) \equiv \lambda C$. Other expenditures apart from the ones derived from the service under analysis add up to an amount $K$, so by definition $\sum_{i=1}^{N} t\left(w_{i}\right) \equiv K$ and hence $\mu \equiv \lambda \frac{C}{K}$.

So what the local government actually does is to choose some weight $\lambda \in[0,1]$ between two alternative ways of financing the service. We remark here that the political decision is not one about public deficit but one about how to finance the service. ${ }^{3}$

We study a model whose timing is as follows. First, a political party $p$ aiming access to office propose a policy $\lambda_{p}$ to citizens, while the ruling party $r$ implements its policy $\lambda_{r}$, indicating at the same time its proposal for the future. With this information, citizens vote, and the winning party becomes the ruling party and implements is proposed policy.

We establish a bipartisan model. We denote the right-wing party as $R$, and we use $L$ for the left-wing party. Both parties know how wealth is distributed among citizens, that is, they know its distribution function $F(F(x)$ is the proportion of citizens whose wealth is equal to or lies

\footnotetext{
${ }^{2}$ The term (marginal-rate) progressivity denotes convexity of the tax function. Likewise, a tax function is (marginal-rate) regressive if it is concave (a recent definition is found in CarbonellNicolau and Ok, 2007). In that sense, we refer to a tax as more progressive than another if it is less (marginal-rate) regressive, that is, less concave. In our paper, $\lambda=1$ represents the most progressive available tax policy, whereas $\lambda=0$ is the most regressive one.

${ }^{3}$ This type of policy could be regarded as earmarking (Bös, 2000; Anesi, 2006). Unlike the latter cited work, we do not focus on the dynamic effects that earmarking has on service-specific
} 
below $x$ ). This avoids uncertainty about the median voter, which is studied in, among others, Roemer (2001) and Ortuño-Ortín (2002). However, Ortuño-Ortín (2002) shares our recognition that party ideology is important, though not necessarily crucial, in determining behavior.

Parties have different utility functions, according to their different ideological preferences:

$$
W_{R}=I\left\{P_{R}>0.5\right\}+v_{R}\left(\lambda_{R}\right) \quad W_{L}=I\left\{P_{L}>0.5\right\}+v_{L}\left(\lambda_{L}\right)
$$

$I$ is an index function which takes value 1 if the statement in braces is true and 0 otherwise. $P_{p}$ is the portion of votes won by party $p$ in the election. $v_{p}\left(\lambda_{p}\right)$ measures the utility that members of party $p$ obtain from proposing its policy. This utility component stems both from purely ideological concerns and from leadership concerns within the political party. Accordingly, $v_{L}(\bullet)$ increases as $v_{R}(\bullet)$ decreases. We assume that these functions take values between 0 and 1 . Thus winning the election constitutes the main aim of each political party.

Our approach departs from the mere political cost minimization postulated by Hettich and Winer [1984, 1988] and by Gill and Haurin [2001]. In our model, politicians' preferences are lexicographic. They give priority to winning the election, but they do not ignore ideological concerns. $^{4}$

Following Roemer (2001, Ch.8), the parties' utility functions in our model represent a compromise between opportunists (who only care about winning election) and militants (who care about the policy the party proposes to the constituency). In this compromise, priority is given to winning the election, and only then do policy proposals seek to satisfy ideological considerations. Roemer finds a third class of actors inside a political party: the so-called reformists (who care about the policy that is actually implemented after the elections), but in order to ease our exposition, they are not taken into account here. Our main result here, the

expenditures and their consequent political implications. We aim instead to analyze the redistributive effects of earmarking, and their political consequences.

${ }^{4}$ We thank a referee for letting us notice that a party obtains utility from its proposal whether it wins or loses the election. 
moderation of policies when party militants and the majority of voters prefer opposite policies, would still hold if we included reformists in the parties' utility functions.

By excluding reformists from our model, we effectively assume that party members do not directly obtain utility from the policy that is finally implemented. This rides on the same assumptions as those found in Persson and Svensson [1989]. Their model predicts that a stubborn conservative politician who is sure she will lose the next election will incur deficits to constrain the capacity of future governments to fund future deficits. Other models such as Tabellini and Alesina [1990], and Alesina and Tabellini [1990] arrive at similar results when parties are likely to alternate in government. In our case, given the utility function we postulate, a conservative politician will incur service-specific deficits in order to maintain his power in a left-wing-social-majority context. To our eyes, this seems more a plausible behavior than surrendering to possible electoral adversity.

The utility functions above indicate that the right-wing party is prone to a more regressive tax structure, while the left-wing party favors more progressive funding. Nevertheless, it is clear that the priority for both parties is to win the election, that is, to achieve (or retain) power. Thus, a party's lexicographic preferences concerning electoral results and applied policy give priority to electoral results.

We initially postulate the following voter $i$ 's utility function:

$$
U_{i}=u\left(w_{i}-(1+\mu) \cdot t\left(w_{i}\right)-(1-\lambda) C / N\right)+g=u\left(w_{i}-(1+\lambda C / K) \cdot t\left(w_{i}\right)-(1-\lambda) C / N\right)+g,
$$

where $u$ is increasing and differentiable. Both $u$ and $g$ could be different across voters, and the results would remain unchanged. We skip the $i$-subscripts for notational convenience.

If we did not include more elements in the model, the median voter theorem would apply and median voter's preferences would lead to a final implementation of either $\lambda=1$ or $\lambda=0$. This common solution found in the literature on median voter. The median voter votes for the 
tax structure that minimizes his tax burden, and the median voter determines the tax policy that wins the election (Blackley and DeBoer, 1987; Stine, 1998).

In our model, we shall assume that the left-wing party is currently governing (had we done the inverse, the conclusions would have been symmetrical), and that each voter has a noneconomic preference for the left-wing party. As pointed out by Groseclose (2001), most valence factors are associated with benefits conferred by incumbency. Among these benefits it is worth noting an established records of positions (Bernhardt and Ingberman, 1985) and public services (Rogoff and Sibert, 1988; Cukierman, 1991), better name recognition (Groseclose, 2001), and better network and negotiation skills (Friedman and Wittman, 1995).

However, since our model is a partial equilibrium one, the valence could be understood as well as the result of voters' preferences that are favorable to the ruling party's policies in other services, apart from the one we study. The valence could also represent mere ideological biases, or a lower uncertainty about candidates' future policies. Thus, we understand that the valence can be explained by various factors that may evolve over time.

An extra value $V_{L}>0$ represents this preference. This valence is attached to any voter's utility when the left-wing party candidate is the mayor. This assumption illuminates the point we want to emphasize: if the ruling party faces an electorate that tends to be prone to a tax policy different from the one most preferred by this party, then the resulting policy would be a moderate one. The valence is constant for simplicity of exposition. It is worth noting that the model keeps its conclusions unchanged when the valence value is non-increasing in wealth level (a surely safer assumption) as long as it remains positive for a sufficiently large amount of voters (a fact observed in Groseclose, 2001). So, we extend the voter's utility function:

$$
\widetilde{U}_{i}=u\left(w_{i}-(1+\lambda C / K) \cdot t\left(w_{i}\right)-(1-\lambda) C / N\right)+g+I\left\{P_{L}>0.5\right\} \cdot V_{L}
$$

Define $\widetilde{w}$ as the wealth that receives the average tax, $t(\widetilde{w}) \equiv K / N$, and $\hat{w}$ as the median wealth. One can see that, if $\hat{w}<\widetilde{w}$, the left-wing party will offer a winning tax policy $\bar{\lambda}_{L}=1$, 
regardless what the right-wing party does. This happens because at least a $F(\widetilde{w})>0.5$ proportion of citizens will inevitably vote for the left-wing party if it offers the most-progressive tax policy, and at the same time the left-wing party, given that it wins, prefers to implement the most-progressive policy.

It is particularly interesting to see what happens when the wealth distribution is such that $\hat{w}>\widetilde{w} .^{5}$ We will see that, in this "conservative" environment, the left-wing party still manages to win the election due to the candidate's valence advantage, yet the tax policy becomes moderate in this case.

First, we deduce the right-wing party's best tax policy proposal strategy. Given some leftwing party proposal $\lambda_{L}$, the right-wing party will choose the minimum tax policy proposal $\lambda_{R}$ that wins the election, if any such value exists. First, notice that no $\lambda_{R}>\lambda_{L}$ can win, as a lambda greater than the left-wing party proposal will obtain a vote share that is bounded above by $F(\widetilde{w})<0.5$. And obviously, $\lambda_{R}=\lambda_{L}$ would yield no votes for the right-wing party, due to the valence disadvantage. Second, notice that if some $\bar{\lambda}_{R}<\lambda_{L}$ beats $\lambda_{L}$, then any $\lambda_{R} \leq \bar{\lambda}_{R}$ also beats $\lambda_{L}$. This is due to $\partial u / \partial \lambda<0$ for any $w_{i}>\widetilde{w}$. A majority of voters see their utilities increased if the right-wing party lowers its proposed lambda, and so they are even more inclined to vote for this party. Therefore, the right-wing party's best tax policy proposal is $\lambda_{R}^{*}=0$, no matter what the left-wing party proposes. In game theoretical terms, $\lambda_{R}^{*}=0$ is a weakly dominant strategy.

\footnotetext{
5 This is not an unlikely scenario. While democratic countries tend to have average income above median income (Roemer 2001, p.9), the opposite inequality may hold in rich municipalities. Besides, a symmetric result would follow in scenarios where average-taxed wealth exceeded median wealth and the right-wing mayor had the valence advantage. Indeed, our empirical analysis provides interesting results in the case where a right-wing mayor coexists with a left-wing constituency.
} 
At this point, the left-wing party has to consider its best response against this conservative proposal in a conservative ambience. So its best policy, $\lambda_{L}^{*}$, is defined as the maximum feasible proposal that obtains at least half of the votes,

$$
\lambda_{L}^{*} \equiv \max \left\{\lambda_{L} \in[0,1]: P_{L}\left(\lambda_{L} \mid \lambda_{R}=0, V_{L}\right) \geq 0.5\right\}
$$

The proportion of votes that go for the leftist party is (weakly) decreasing in its tax policy proposal. This is due to $\partial u / \partial \lambda<0$ for any $w_{i}>\widetilde{w}$, plus the fact that all voters $i$ with $w_{i} \leq \widetilde{w}$ will always vote for the leftist party, given $\lambda_{R}^{*}=0$. Since $P_{L}\left(0 \mid \lambda_{R}=0, V_{L}\right)=1$, due to the valence advantage, we conclude that $\lambda_{L}^{*}$ exists and is unique. We shall point out that this value may not be equal to (the minimum between 1 and) the tax policy proposal that makes the median-wealth voter indifferent, unless additional assumptions on the shape of the utility function are imposed.

The left-wing party candidate's popularity, or valence, is sufficient for this party to win the election. Yet, if the interests of the majority are right-wing oriented and the valence is sufficiently small, the left-wing party will moderate its tax policy with respect to its mostpreferred, i.e. most-progressive, one yielding a (partial) equilibrium policy $\lambda^{*}=\lambda_{L}^{*}$.

As a generalization, if both valences and socioeconomic interests point to the same ideological side, the ruling party will undertake its most-preferred tax policy in order to pay for public service production. We call this idea Hypothesis A. Otherwise, if non-economic biases favor one party but economic preferences favor the other one, the resulting tax policy will be a moderate one. This will be regarded as Hypothesis B.

\section{Empirical strategy}

In order to test our hypotheses, we use data concerning waste management services from a sample of 186 Spanish municipalities in Catalonia. This region offers an interesting case study for several reasons. First, solid waste is subject to regional regulation in Spain; hence, regional analysis benefits from homogeneity regarding supra-municipal regulation of the production and financing of the service. Second, the city structure in Catalonia is very diverse, including large cities and metropolitan areas, as a well as a large number of towns and small cities. This 
diversity enriches our study because it allows separate analysis of large urban areas and small cities and towns.

Furthermore, many local services in the Catalonian municipalities are not fully funded by service fees, because there is no legal obligation to do so, and mixed funding (service fees plus budget funding) is common. This is the case of the most significant services such as solid waste collection and treatment, water distribution and treatment, and local public transportation (particularly in the metropolitan area of Barcelona), as well as other services such as public sports facilities and cultural events. Of course, by choosing solid waste collection we do not imply that voting depends particularly on the funding choice for this service. What we have in mind is that choices made by governments regarding solid waste (for which data collection on service costs and service-fee revenues, even if burdensome, is possible) likely reflect a more general approach to the choice between progressive and regressive taxation in the municipality, and this general approach might indeed influence voting behavior.

To carry our empirical analysis, we have obtained data concerning the waste management service from a sample of 186 Spanish municipalities in Catalonia. These data have been collected thru the $1^{\text {st }}$ Local Service Production Survey (LSPS from now on), which was developed and conducted by the University of Barcelona. The LSPS sought information about solid waste collection and treatment services in the year 2000. The survey asked whether the waste collection service was privately produced. It also requested data on total municipality payments to private firms plus monitoring costs in cases of concession/delegation or total cost in cases of public production. It further asked about service-specific fees collected. 11 municipalities from the sample did not provide enough information, so our sample was reduced to 175 municipalities for the purposes of this paper. Finally, we could not obtain public finance data for five of these municipalities, so that our estimation utilizes 170 municipalities.

Other useful data have been obtained from the Catalonian Waste Treatment Agency. Variables included are the total number of tons collected in each municipality during both the period under consideration and the previous year. From the Audit Commission of Catalonia, we have data on municipalities' financial difficulties during 2000, and on the nature of tax returns 
over the same period. From the Spanish Statistical Institute (INE) and the Catalonia Statistical Institute (Idescat), data have been obtained on relevant political and social variables.

We construct, estimate and test a simple econometric model in order to assess the extent to which our hypotheses are right. The illustrative model in the previous section predicts whether the political outcome will be moderate, but it does not explicitly predict a value for the relation between budget and fee financing. Therefore, the econometric model cannot be fully structural ${ }^{6}$. We therefore approach our studied variable, the service-specific deficit, as a function of variables that proxy valence advantages and socioeconomic interests. Other control variables are added as well.

We use a Tobit likelihood equation:

$$
L\left(\lambda_{i} \mid X_{i}\right)=\left[1-F\left(1-h\left(X_{i}\right)\right)\right]^{I\left\{\lambda_{i}=1\right\}} \cdot f\left[\lambda_{i}-h\left(X_{i}\right)\right]^{I\left\{0<\lambda_{i}<1\right\}} \cdot F\left[-h\left(X_{i}\right)\right]^{I\left\{\lambda_{i}=0\right\}}
$$

Here, $F$ is the normal distribution function with zero mean variance $\sigma^{2}$ (to be estimated), $f$ is the associated density function and $h$ is a linear function whose parameters are to be estimated. $I$ is the usual index function, which takes value 1 if the expression in braces is true and 0 otherwise.

For each municipality $i$ in 2000, this equation tries to explain the Service-Specific Deficit $(\lambda$, or our $\lambda^{*}$ in the theoretical illustration) as a function of variables $(X)$ including: Expenditure Prediction Errors, variables related to Financial Difficulties, the mode of service production (concretely, a Private Production variable), political variables and social variables, plus some other control variables that help us obtain unbiased estimates. The effects of political and social variables constitute the main concern of our study.

\footnotetext{
${ }^{6}$ If we imposed $\partial^{2} u / \partial \lambda \partial w_{i}<0$, we would be able to predict the winning policy proposal as the one that makes the median voter indifferent between the left-wing party and the right-wing party (if it belongs to $(0,1)$ ). Imposing such a condition requires additional assumptions on the utility function that may not be plausible enough.
} 
$\lambda$ is measured as 1 minus the ratio of service-specific fee collected to total service cost. This is a value that, according to Spanish legislation, must lie between 0 and 1, as service-specific tax returns should never be higher than service-specific production costs ${ }^{7}$.

The Expenditure Prediction Error is approached as the ratio between total solid waste collected in 2000 and total solid waste collected in 1999. This variable constitutes a proxy since it is assumed that prediction errors are positively correlated with the growth ratio of solid waste generation. The more service production grows, the more likely a politician would be to make errors in predicting service costs.

Financial Difficulties are approached through the Global Financial Burden Index, which is the percentage of municipal debt-related expenditures over current revenues ${ }^{8}$. This index is a good indicator of municipal financial difficulties. It is presumed that higher difficulties may force the mayor to search for a lower service-specific deficit level.

Private Production is a dummy variable that takes value 1 if the service was private in 2000 and 0 otherwise. It could be the case that the service-specific deficit level is lower in municipalities with private delivery, since they may have taken advantage of this reform to increase service-specific revenues and decrease subsidies from the budget.

Concerning political and social variables, we have taken some alternative approaches in trying to reflect the political and social context that the mayor faces. These approaches refer to a double dimension of the political context. One of them is the dilemma between whether the ideological identity of the ruling mayor matters or, on the contrary, the social majority's interests rule the service-specific deficit decision. The dimension concerns the fact that other parties could influence the mayor's decisions, because the governing party may need to rule in

\footnotetext{
${ }^{7}$ By this reasoning, all service-specific deficit levels that, after being calculated from reported responses to the LSPS, resulted in negative numbers have been considered as either measurement errors or policymaker's ones and therefore converted into zero values. There are only 3 such cases. Results do not change if we drop them out of the sample.

${ }^{8}$ Data for this variable refer to the year 1999, as the politician may react only to known variables. At the same time, by choosing that year we avoid endogeneity problems that might be induced by the Financial Difficulties variable.
} 
coalition. The former dimension is related to our illustrative model and hypotheses, while the latter dimension is used to test other explanations found in earlier literature (Roubini and Sachs, 1989; Edin and Ohlsson, 1991).

The reader should keep in mind that the mayor's ideological identity is a good measure of non-economic electoral biases because valences determine the identity of the ruling party. Social majority measures, on the other hand, have to do with pure economic interests the theoretical section suggests will determine the extent of tax policy moderation.

In order to address the different dimensions of the socio-political context, we have undertaken different estimations. In the first, the variables Mayor's Ideological Affiliation and Minority government (the latter variable suggested in Edin and Ohlsson, 1991) are used. Mayor's Ideology is a dummy variable that takes value 1 if the mayor is a member of a leftist party or organization, and 0 otherwise. Minority is also measured as a dummy, which in this case takes value 1 if there is neither a party nor a stable coalition that achieves majority in the municipal council.

In a second approach, the variables Mayor's Ideology and Roubini-Sachs (the Roubini and Sachs index) are used. The Roubini and Sachs index is a discrete variable that takes value 0 if one party is governing the municipality with a majority, 1 if two parties are needed form a coalition in order to rule the municipality, 2 if three or more parties are needed to form a governing coalition and 3 if there is a minority government ${ }^{9}$. According to Roubini and Sachs (1989), the presence of many political parties in a governing coalition could be associated with a low ability to reduce deficits (Edin and Ohlsson, 1991). But Edin and Ohlsson found that the Roubini and Sachs effects could be better captured by a simple minority dummy. Edin and Ohlsson conclude that governing in minority is even harder than, and needs as least as much negotiation effort, as governing in coalition ${ }^{10}$. We therefore address the weakness of the

\footnotetext{
${ }^{9}$ Hence, value 3 in Roubini-Sachs has the same meaning as value 1 in Minority.

${ }^{10}$ Haan and Sturm (1997) and Ricciuti (2004) find that neither the Roubini-Sachs approach nor the Minority approach explain government debt at a cross-country level. Galli and Padovano (2002), however, find evidence for Italy in favor of government fragmentation as a variable that influences deficit policies.
} 
governing party by means of two approaches, that is, the Minority dummy and the RoubiniSachs variable.

In a third approach, we use the variables Constituency's Interests and Minority. Constituency's Interests (which are referred to many times in this paper as "social majority") is measured as a dummy variable. It takes value 1 if the sum of votes received by leftist parties in the Spanish national elections of 1996 and 2000 is more than half of the total votes. These two elections surround the 1999 municipal elections. It takes value 0 otherwise. This variable is conceived as a proxy for the social majority underlies a mayor's policies. It is commonly thought that the national election vote is related to social class considerations. A simple regression of Constituency's Interests on local per capita income confirms this idea for our sample; results are shown in the Appendix. It is expected that this variable will also be positively correlated with service-specific deficit levels.

A fourth approach combines Constituency’s Interests and Roubini-Sachs Index.

A fifth approach looks at interactions between Mayor's Ideology and Constituency's Interests, hence creating the following dummies: LeftM-LeftC (Leftist governing party - Leftist social majority, or $L L$ for short), LeftM-RightC (Leftist governing party - Rightist social majority, $L R$ ), and RightM-LeftC (Rightist governing party - Leftist social majority, $R L$ ). These dummies are easy to understand and need not be explained. This model is much more complete and useful from our point of view, as it allows us to check all the hypotheses developed in the preceding section:

$$
\begin{array}{ll}
\text { By Hypothesis A: } & \operatorname{coef}(L L)>>0 \\
\text { By Hypothesis B: } & \operatorname{coef}(L L)>\operatorname{coef}(L R) \\
& \operatorname{coef}(R L)>0
\end{array}
$$

In this fifth approach, Minority is used as the indicator of political weakness. Finally, a sixth approach uses the Roubini-Sachs Index instead. The table 1 summarizes our main variables and hypotheses. Table 2 summarizes all the approaches we take.

\section{(Insert table 1 here)}

(Insert table 2 here) 
In all the combinations tested, we control for the Overall Progressiveness of the municipal tax structure. By doing so, we avoid the risk of bias that stems from the fact that service-specific deficit could be higher simply because the tax structure of the municipality is generally less based on fees. One could observe that this variable might play a role similar to that of a fixed effect in a panel data analysis, which is quite convenient from our point of view, since there are no available panel data on poll taxes and solid waste treatment costs in our sample. Our Overall Progressiveness variable is calculated as the percentage of "direct tax" revenues with respect to total tax revenues, comparing collected taxes ${ }^{11}$. "Direct taxes" include the Property Tax, the Economic Activity Tax, the Motor Vehicle Tax and the Tax on the Increase of Real Estate Value. Most of them have highly progressive rates. The Property Tax is the one that generates the highest portion of tax-driven revenues, and it is a particularly progressive tax. ${ }^{12}$

Finally, we shall take the possibility of spatial correlation into account. It is reasonable to believe that fiscal policies might be correlated among municipalities of the same region. In order to test that effect, we ran auxiliary estimations including regional dummies, one for each "Àmbit Territorial” (Territorial Unit). Catalonia currently has seven "Àmbits", so six regional dummies were used as additional explanatory variables. We tested the overall significance of the coefficients associated to the regional dummies. In no case were the coefficients overall significant, and no coefficient was individually significant either. Therefore, we provide only the results of the main estimations, which do not include regional dummies, plus the test statistics concerning the regional dummies.

\section{Results}

We estimate these different approaches, or models, by using Stata 8.0 statistical software. Table 3 displays results for the whole sample. Likelihood Ratio Stability Tests are conducted for each equation. These tests are justified by the fact that political decisions concerning service-specific deficits may be motivated by different factors depending on municipality size.

In small municipalities, decisions could be related to personal rather than ideological motivations. Service-specific deficits are presumably explained more often by cost prediction

${ }^{11}$ Estimations using budgeted data yield almost identical results. They are available on request. 
errors in low-populated municipalities than in high-populated ones. In the latter municipalities, social and political factors could have much more influence on a mayor's decisions. Besides, the Expenditure Prediction Error proxy may perform well in low-populated municipalities, with less skilled bureaucrats on average and, hence, more simple prediction mechanisms, but may be less effective in high-population municipalities, which have more complex prediction formulas. The chosen population breakpoint is approximated to 5,000 inhabitants. In our sample, this breakpoint splits our observations approximately in half.

Whole sample estimations perform quite well for models 5 and 6 since the pseudo $\mathrm{R}^{2}$ lies above 0.70 in the respective tables. They also perform well for equations 3 and 4 , with pseudo $\mathrm{R}^{2}$ lying slightly below 0.70 . Performance is definitely worse for equations 1 and 2 , with pseudo $\mathrm{R}^{2}$ around 0.20 . These results suggest that service-specific deficit level decision depends more on social majorities than on a mayor's declared ideology or non-economic biases. They also suggest that a combination of a mayor's ideology and social majorities is what explains the service-specific deficit decision best.

The stability tests do not leave us with a clear conclusion. While models 1 and 2 are obviously unstable, in models 3 and 4 the stability hypothesis is rejected only at the $10 \%$ significance level, while in models 5 and 6 this hypothesis is not even rejected (although the resulting test is not very conclusive). Sub-sample estimations are reported in tables 4 and 5 .

\section{(Insert table 3 here) \\ (Insert table 4 here) \\ (Insert table 5 here)}

Main results. models 5 and 6 merit the most extensive discussion as they are both possessed of more explanatory power and richer than models 1 through 4 . Moreover, the evidence from the latter models does not contradict what is found in the former models. In models 5 and 6 , differences between coefficients are in many cases more intense in the big-municipalities subsample than in the small-municipalities one. Regarding the hypotheses we want to test, we can observe the following facts:

\footnotetext{
${ }^{12}$ The Catalonia Audit Commission has kindly provided data.
} 
A) For any sub-sample and for the whole sample, the LeftM-LeftC coefficient is significantly positive, at the $1 \%$ level. The service-specific deficit level is between 34 and 50 percentage points higher in municipalities with leftist mayors and leftist social majorities than in municipalities with rightist mayors and rightist social majorities. This gives support to Hypothesis A. Although a $100 \%$ absolute gap would be the theoretical prediction, empirical data shows that our model partially fits the fact that the deficit gap between these two types of municipality is huge. Recall that the theoretical model is only illustrative.

B) The RightM-LeftC coefficient is positive and significant in the big-municipalities subsample and in the whole sample, while it is not so in the small-municipalities sub-sample. Nevertheless, it should be noted that there is only one observation in the latter sub-sample that takes value 1 for this dummy, so that coefficient estimation in this case is difficult to evaluate. Thus there is some support to the idea, reflected in Hypothesis B, that social majority matters in policy design even when it does not coincide with the mayor's political sign. Rightist mayors adopt more leftist tax schemes when they face a leftist social majority.

C) There is a positive difference between the LeftM-LeftC coefficient and that for LeftMRightC. This difference is significant at the $1 \%$ level in any of the estimations, and quite similar in any of them, lying between 30 and 41 percentage points. This constitutes heavy support to our Hypothesis B.

What is observed in models 5 and 6 supports our previous hypotheses, though some of the evidence should be taken with caution. First, the full sample estimation passes the stability test, though maybe not convincingly enough. Second, the RightM-LeftM variable (Right-wing governing party and Left-wing social majority) has scant variability, so that coefficients obtained are not as precise as desired. Finally, we have noticed that our hypotheses perform better in big municipalities than in small ones. This may be certainly due to the fact that small government structures follow a more personal relationship with the community, hence smoothing ideological differences among the different political organizations competing for a place in office.

Brief comments are in order, concerning the sociopolitical variables in models 1 through 4 . In models 1 and 2, we see that a leftist mayor is associated with higher service-specific deficit 
levels than a rightist one, but this effect is only significant for big municipalities. The leftistmayor effect lies between 6 and 24 percentage points, the lower differences concentrating in small municipalities. In equations 3 and 4, we see that a higher proportion of leftist vote in national elections (leftist social majority) is connected to higher service-specific deficit levels, at a $1 \%$ level in any estimation, and regardless of the municipality size. The effect is lower in small municipalities, around 25 percentage points. It is stronger in big municipalities, roughly above 42 percentage points.

Control variables and side results. A variable that performs quite well is Private Production. Evidence shows that waste collection service privatization has had a significant, negative effect on service-specific deficits. Ceteris paribus, privatization reduces this deficit by 10 percentage points. This suggests that policymakers have used privatization as a means to reduce the political cost of increasing service-specific taxes, particularly if we take into account that privatization of solid waste collection is not significantly related to governments' ideological biases (Bel and Fageda, 2007, 2009).

While the mode of production has no apparent effect on highly populated municipalities' service-specific deficit, it does have an important and significant effect on the deficit in small municipalities. Thus, notwithstanding the general explanation for the significant effect of this variable, privatization can additionally be thought as a way to avoid the consequences of recurrent cost prediction errors in small municipalities.

The main source of municipality-size-related instability in the estimation comes from the Expenditure Prediction Error proxy. While its attached coefficient is positive and significant in any model for the small-municipalities sub-sample, its sign is negative and not significant for the big-municipalities sub-sample. The result observed for the big-municipalities sample should not be very astonishing. It is explained, on the one hand, by the fact that large municipalities have high-skilled bureaucrats able to use prediction mechanisms that are much more sophisticated than the simple one-lag system. Therefore, our prediction error variable does not perfectly approach real prediction errors in the big-municipalities sub-sample, so the attached coefficient is meaningless to some extent. Smaller municipalities with low-skilled bureaucrats 
use simple prediction mechanisms and hence our prediction error variable performs much better on the respective sub-sample.

The minority effects are not significant at all regardless of the way they are measured, suggesting that they may be more important when deciding the global deficit than when deciding service-specific ones. Neither Roubini and Sachs's (1989) nor Edin and Ohlsson's (1991) predictions are met in our study. A reason for this finding could be that we are not studying proper deficit decisions but the way in which a specific service is funded.

Financial Difficulties have no effect on the service-specific deficit ${ }^{13}$. This makes sense, since budgetary shortcomings tend to induce increased effort in raising revenues rather than in redistributing the source of these returns.

Finally, including a control variable regarding the overall progressiveness of the tax structure was a good idea. We observe that it has a significant effect in most aggregated estimations, and that significance test statistics are not very low even in cases where the coefficients are not significant at the $10 \%$ level. Thus, we should not ignore that service-specific finance decisions may be correlated with the general tax structure.

\section{Conclusions}

In this paper, we build a few simple theoretical predictions concerning the way politicians choose between progressive and regressive tax schemes to fund local service production costs. We base our ideas on a bipartisan context in which each party's preferences are lexicographic, giving priority to winning but following ideological preferences when victory is obtained. Concerning voters, we distinguish between non-economic biases in favor of one candidate and pure individualistic economic interests. We then predict what happens when both types of preferences point to the same ideological side and what happens when these dimensions of preferences are in conflict. The tax policy becomes a moderate balance between the ruling party's ideological preferences and social majority's preferences. We understand social majority as the aggregation of pure economic interests among the different voters.

\footnotetext{
${ }^{13}$ We ran our estimations without the Financial Difficulties variable, and results are unchanged. They are available on request.
} 
These ideas are tested on a wide sample of municipalities regarding the way in which they finance waste collection and treatment services. A service-specific deficit level, constructed from the difference between service costs and service-specific fee revenues, is funded through the general, more progressive municipal tax scheme. This service-specific deficit is regressed over explanatory variables including variables reflecting non-economic biases (measured as the ideological sign of the ruling party) and social majorities' interests (approached through results in national elections).

We use the Tobit procedure. Our empirical estimation arrives at distinct conclusions for very small municipalities, given that policymakers in that case follow personal more than either ideological or pragmatic motivations when setting the funding scheme. This is also due to the fact that small municipalities' service-specific deficits respond more to prediction errors and difficulties in controlling for public accounts.

For the whole sample, and above all for big municipalities, our estimations perform quite well in support of our hypotheses. There is a clear difference between the taxation schemes followed in a leftist-ruling-party, leftist-social-majority municipality and the ones practiced in a rightist-ruling-party, rightist-social-majority municipality. Where there is divergence between non-economic biases and social majorities, tax policies tend to be moderated. The result is a balance between the social majority's preferences and those of the ruling political party.

An additional result we believe worth emphasizing is that privatization of the service is significantly associated with higher levels of service-specific fees funding. This suggests that policymakers may have used privatization as a means of reducing the political cost from increasing service-specific taxes, thus reducing the service-specific deficit.

By means of simple theoretical ideas incorporating both private interests and ideology in parties' utility functions, we have devised an alternative empirical tool that contributes to explaining why tax policies sometimes become more moderate than what a simple median voter model would predict. We are aware that there exist other approaches that could explain, as well, part of this phenomenon. One reflects the actual uncertainty about median voter's preferences. Another explains tax scheme diversity through a tax policy political cost minimization problem. 
Further research will try to combine different assumptions in order to develop and test a more integrated model. 


\section{Appendix: Relation between national election vote and individual wealth.}

To support the idea that national election vote is related to individual wealth, we have regressed the Leftist Constituency variable on per capita income. As exact data on local income per capita is not available, we have used the estimated per capita income index (PCII) that is elaborated by "La Caixa", referring to year 2000. This index lies in a range from 0 thru 10 , where 10 is the maximum level of (estimated) local income per capita. We seek to empirically prove that this relation is stronger at a national election level than at a local election one, which is a critical issue of our paper. To do so, we estimate Probit models relating the governing party's ideological identity and social majorities with the per capita income index. Results are shown in table A-1.

\section{(Insert table A-1 here)}

The relation between income per capita and mayor's ideological identity is much weaker than the one between income and social majority (national election vote). For instance, the log likelihood and the Pseudo R-squared are much higher in the latter model.

Table A-1: A comparison of the influence of per capita income on national and local election vote.

\begin{tabular}{|l|c|c|}
\hline & Explained dummy: & $\begin{array}{l}\text { Explained dummy: } \\
\text { Leftist majority (>50\% votes) in last } \\
\text { national elections. }\end{array}$ \\
\hline PCII & -0.2025349 & -0.6692689 \\
& $(-2.32)^{* *}$ & $(-4.92)^{* * *}$ \\
\hline Constant & 1.666457 & 4.259356 \\
& $(2.44)^{* *}$ & $(4.29)^{* * *}$ \\
\hline F & $5.45++$ & $32.48+++$ \\
\hline Log likelihood & -118.09257 & -79.028506 \\
\hline Pseudo R-squared & 0.0226 & 0.1705 \\
\hline $\mathrm{N}$ & 175 & 175 \\
\hline
\end{tabular}

Notes: $\quad * * *$ significant at $1 \%$ level, $* *$ at $5 \%, *$ at $10 \%$.

+++ null hypothesis rejected at $1 \%$ level, ++ at $5 \%$, + at $10 \%$.

In brackets, z-statistic values (null hypothesis: value equal to zero). 


\section{References}

Alesina A, 1988, "Credibility and policy convergence in a two party system with rational voters" American Economic Review 78(4) 796-806

Alesina A, Tabellini G 1990, "A positive theory of fiscal deficits and government debt" Review of Economic Studies 57(3) 403-414.

Anesi V, 2006, "Earmarked taxation and political competition" Journal of Public Economics $90(4-5) 679-701$.

Ansolabehere S, Snyder J, 2000, "Valence politics and equilibrium in spatial election models" Public Choice 103(3-4) 327-336.

Beesley T, Coate S, 1997, "An economic model of representative democracy" Quarterly Journal of Economics 112(1) 85-114.

Beesley T, Case A, 2003, "Political institutions and policy outcomes" Journal of Economic Literature 41(1) 7-73.

Bel G, 2002, "Privatización de servicios locales: Algunas implicaciones sobre la tasa de los usuarios y el presupuesto" Análisis Local 0(45) 45-58.

Bel G, Fageda X, 2007, "Why do local governments privatize public services? A survey of empirical studies" Local Government Studies 33(4) 517-534.

Bel G, Fageda X, 2009, "Factors explaining local privatization: a meta-regression analysis" Public Choice 139(1/2) 105-119.

Bel G, Warner M, 2008, "Challenging issues in local privatization" Environment and Planning C: Government and Policy 26(1) $104-109$.

Bernhardt D, Ingberman D, 1985, "Candidate reputation and the incumbency effect" Journal of Public Economics 27(1) 47-67.

Biegeleisen A, Sjoquist D, 1988, "Rational voting app.lied to choice of taxes" Public Choice 57(1) 39-47.

Bird R M, Slack E, 2007, "An approach to metropolitan governance and finance" Environment and Planning C: Government and Policy 25(5) 729 - 755.

Blackley P, DeBoer L, 1987, “Tax base choice by local governments” Land Economics 63(3) 227-236. 
Bös D, 2000, "Earmarked taxation: welfare versus political support" Journal of Public Economics 75(4-5) 439-462.

Calvert R, 1985, "Robustness of the multidimensional voting model: candidate motivations, uncertainty and convergence" American Journal of Political Science 29(1) 69-95

Carbonell-Nicolau O, Ok E, 2007, "Voting over income taxation" Journal of Economic Theory 134 (1) 249-286.

Coate S, Colin M, (2004 "A Group Rule-Utilitarian Approach to Voter Turnout: Theory and Evidence" American Economic Review 94(5) 1476-1504..

Cukierman A, 1991, "Asymmetric information and the electoral momentum of public opinion polls" Public Choice 70(2) 181-213.

de Haan J, Sturm JE, 1997, "Political and economic determinants of oecd budget deficits and government expenditures: a reinvestigation“ European Journal of Political Economy 13(4) 739-750.

Dijkgraaf E, Gradus R, 2004, "Cost savings of unit-based pricing of household waste: The case of the Netherlands" Resource and Energy Economics 26(4) 353-371

Dixit A, Londregan J, 1998, "Ideology, tactics, and efficiency in redistributive politics" Quarterly Journal of Economics 113(2) 497-529.

Downs A, 1957 An Economic Theory of Democracy (Harper and Row, New York (NY).

Edin PA, Ohlsson H, 1991, "Political determinants of budget deficits: coalition effects versus minority effects“ European Economic Review 35(8) 1597-1603.

Friedman D, Wittman D, 1995, "Why voters vote for incumbents but against incumbency: a rational choice explanation" Journal of Public Economics 57(1) 67-83.

Galli E, Padovano F, 2002, "A comparative test of alternative theories of the determinants of Italian public deficits (1950-1998)“ Public Choice 113(1-2) 37-58.

Gill L, Haurin D, 2001, “The choice of tax base by Local authorities: voter preferences, special interest groups, and tax base diversification" Regional Science and Urban Economics 31(6) 733-749.

Groseclose T, 2001, "A model of candidate location when one candidate has a valence advantage" American Journal of Political Science 45(4) 862-886. 
Hebdon R, Jalette P, 2008, "The restructuring of municipal services: a Canada - United States comparison" Environment and Planning C: Government and Policy 26(1) 144 - 158.

Henderson JV, 1994, "Community choice of revenue instruments" Regional Science and Urban Economics 24(2) 159-183.

Hettich W, Winer S, 1984, "A positive model of tax structure" Journal of Public Economics 24(1) 67-87.

Hettich W, Winer S, 1988, "Economic and political foundations of tax structure" American Economic Review 78(4) 701-712.

Lago-Peñas S, 2005, "Evolving federations and regional public deficits: testing the bailout hypothesis in the Spanish case " Environment and Planning C: Government and Policy 23(3) $437-453$.

Norstrand R, 1980, "The choice between income-tax and land tax in Danish municipalities" Public Finance 35(3) 412-423.

Ortuño-Ortín I, 2002 "Ideological versus Downsian political competition" Social Choice and Welfare 19(3) 551-567.

Persson T, Svensson L, 1989, "Why a stubborn conservative would run a deficit: policy with time-inconsistent preferences“ Quarterly Journal of Economics 104(2) 325-345.

Ricciuti R, 2004, "Political fragmentation and fiscal outcomes" Public Choice 118(3-4) 365388.

Rodríguez-Pose A, Sandall R, 2008, "From identity to the economy: analysing the evolution of the decentralisation discourse" Environment and Planning C: Government and Policy 26(1) $54-72$.

Roemer JE, 2001 Political Competition: Theory and Applications (Harvard University Press, Cambridge (MA).

Rogoff K, Sibert A, 1988, "Elections and macroeconomic policy cycles" Review of Economic Studies 55(1) 1-16.

Roubini N, Sachs J, 1989, "Political and economic determinants of budget deficits in the industrial democracies“ European Economic Review 33(5) 903-933. 
Stine W, 1998, "Explaining the decision to repeal an optional local tax" Applied Economics 30(3) 353-363.

Tabellini G, Alesina A, 1990, "Voting on the budget deficit" American Economic Review 80(1) $37-49$.

Wittman D, 1983, "Candidate motivation: A synthesis of alternative theories" American Political Science Review 77(1) 142-157

Wittman D, 2005, "Valence characteristics, costly policy and the median-crossing property: a diagrammatic exposition" Public Choice 124(3) 365-382. 
Table 1. Main variables and hypotheses.

\begin{tabular}{|l|l|l|}
\hline Variable & Hypothesis & Data Source \\
\hline$\lambda$ : Service-Specific Deficit & Dependent variable & Local Services Production Survey \\
\hline Expenditure Prediction Errors & $\begin{array}{l}\text { Prediction errors } \\
\text { increase } \lambda\end{array}$ & Catalonia Waste Treatment Agency \\
\hline $\begin{array}{l}\text { Financial Difficulties (Global Financial } \\
\text { Burden Index) }\end{array}$ & $\begin{array}{l}\text { Financial difficulties } \\
\text { increase } \lambda\end{array}$ & Catalonia Audit Commission \\
\hline Mode of Production & $\begin{array}{l}\text { Private production } \\
\text { decreases } \lambda\end{array}$ & Local Services Production Survey \\
\hline Mayor's Ideological Affiliation & $\begin{array}{l}\text { Left-wing Mayor } \\
\text { increases } \lambda\end{array}$ & INE and Idescat \\
\hline $\begin{array}{l}\text { Constituency's Interests } \\
\text { (Social majority) }\end{array}$ & $\begin{array}{l}\text { Left-wing } \\
\text { constituency } \\
\text { increases } \lambda\end{array}$ & INE and Idescat \\
\hline
\end{tabular}

Table 2. Different empirical approaches used to explain service-specific deficits.

\begin{tabular}{|l|l|l|}
\hline Effects of non-economic bias & Effects of economic interests & $\begin{array}{l}\text { Effects of combinations } \\
\text { (Hypotheses A and B) }\end{array}$ \\
\hline $\begin{array}{l}\text { 1) Mayor's Ideology } \\
\text { + Minority }\end{array}$ & $\begin{array}{l}\text { 3) Constituency's Interests } \\
\text { + Minority }\end{array}$ & $\begin{array}{l}\text { 5) Mayor-Constit. Combination } \\
\text { + Minority }\end{array}$ \\
\hline $\begin{array}{l}\text { 2) Mayor's Ideology } \\
\text { + Roubini-Sachs }\end{array}$ & $\begin{array}{l}\text { 4) Constituency's Interests } \\
\text { + Roubini-Sachs }\end{array}$ & $\begin{array}{l}\text { 6) Mayor-Constit. Combination } \\
\text { + Roubini-Sachs }\end{array}$ \\
\hline
\end{tabular}


Table 3. Factors explaining service-specific deficit level. Whole sample $(\mathrm{N}=170)$.

\begin{tabular}{|c|c|c|c|c|c|c|}
\hline Variable & Model 1 & Model 2 & \begin{tabular}{|l|} 
Model 3 \\
\end{tabular} & Model 4 & Model 5 & Model 6 \\
\hline $\begin{array}{l}\text { Expenditure } \\
\text { Prediction Error }\end{array}$ & $\begin{array}{c}0.2708 \\
(1.39) \\
\end{array}$ & $\begin{array}{c}0.2778 \\
(1.43) \\
\end{array}$ & $\begin{array}{c}0.2839^{*} \\
(1.86) \\
\end{array}$ & $\begin{array}{c}0.2959^{*} \\
(1.93) \\
\end{array}$ & $\begin{array}{c}0.2293 \\
(1.53) \\
\end{array}$ & $\begin{array}{c}0.2390 \\
(1.59) \\
\end{array}$ \\
\hline $\begin{array}{l}\text { Financial } \\
\text { Difficulties }\end{array}$ & $\begin{array}{l}0.0007 \\
(0.15)\end{array}$ & $\begin{array}{l}0.0010 \\
(0.22)\end{array}$ & $\begin{array}{c}-0.0007 \\
(-0.19) \\
\end{array}$ & $\begin{array}{c}-0.0009 \\
(-0.25)\end{array}$ & $\begin{array}{c}-0.0006 \\
(-0.17) \\
\end{array}$ & $\begin{array}{c}-0.0007 \\
(-0.21) \\
\end{array}$ \\
\hline Private Production & $\begin{array}{l}-0.0929 \\
(-1.59) \\
\end{array}$ & $\begin{array}{c}-0.0936 \\
(-1.61) \\
\end{array}$ & $\begin{array}{c}-0.1079 * * \\
(-2.35)\end{array}$ & $\begin{array}{c}-0.1125^{* *} \\
(-2.44)\end{array}$ & $\begin{array}{c}-0.0987 * * \\
(-2.20)\end{array}$ & $\begin{array}{c}-0.1024 * * \\
(-2.28)\end{array}$ \\
\hline Leftist Mayor & $\begin{array}{c}0.1737 * * * \\
(3.89)\end{array}$ & $\begin{array}{c}0.1790 * * * \\
(4.00)\end{array}$ & & & & \\
\hline Leftist Constituency & & & $\begin{array}{c}0.4091 * * * \\
(10.11)\end{array}$ & $\begin{array}{c}0.4086^{* * * *} \\
(10.03)\end{array}$ & & \\
\hline LeftM-LeftC (LL) & & & & & $\begin{array}{c}0.4756^{* * * *} \\
(10.08)\end{array}$ & $\begin{array}{c}0.4766 * * * \\
(10.06) \\
\end{array}$ \\
\hline LeftM-RightC (LR) & & & & & $\begin{array}{c}0.0515 \\
(1.32) \\
\end{array}$ & $\begin{array}{l}0.0533 \\
(1.34) \\
\end{array}$ \\
\hline RightM-LeftC (RL) & & & & & $\begin{array}{c}0.2719 * * * \\
(3.38)\end{array}$ & $\begin{array}{c}0.2690 * * * \\
(3.32)\end{array}$ \\
\hline Minority & $\begin{array}{c}0.0050 \\
(0.05) \\
\end{array}$ & & $\begin{array}{l}0.1037 \\
(1.45) \\
\end{array}$ & & $\begin{array}{c}0.0844 \\
(1.20) \\
\end{array}$ & \\
\hline Roubini-Sachs & & $\begin{array}{c}-0.0163 \\
(-0.68) \\
\end{array}$ & & $\begin{array}{l}0.0167 \\
(0.90)\end{array}$ & & $\begin{array}{l}0.0122 \\
(0.66) \\
\end{array}$ \\
\hline $\begin{array}{l}\text { Overall } \\
\text { Progressiveness }\end{array}$ & $\begin{array}{c}0.0056^{* * * *} \\
(2.80)\end{array}$ & $\begin{array}{c}.0056 * * * \\
(2.79) \\
\end{array}$ & $\begin{array}{c}0.0035^{* *} \\
(2.18) \\
\end{array}$ & $\begin{array}{c}0.0034^{* *} \\
(2.13)\end{array}$ & $\begin{array}{l}0.0024 \\
(1.54) \\
\end{array}$ & $\begin{array}{l}0.0024 \\
(1.49) \\
\end{array}$ \\
\hline Constant & $\begin{array}{c}-0.5381 * * \\
(-2.09)\end{array}$ & $\begin{array}{c}-0.5375^{* *} \\
(-2.09)\end{array}$ & $\begin{array}{c}-0.3982^{*} \\
(-1.96)\end{array}$ & $\begin{array}{c}-0.4069^{* *} \\
(-2.00)\end{array}$ & $\begin{array}{c}-0.3109 \\
(-1.54)\end{array}$ & $\begin{array}{c}-0.3171 \\
(-1.56)\end{array}$ \\
\hline LR test full model & $27.92+++$ & $28.39+++$ & $93.44+++$ & $92.16+++$ & $100.70+++$ & $99.71+++$ \\
\hline Pseudo $\mathrm{R}^{2}$ & 0.2069 & 0.2104 & 0.6924 & 0.6829 & 0.7462 & 0.7388 \\
\hline F regional dummies & 1.61 & 1.62 & 0.87 & 0.93 & 0.71 & 0.75 \\
\hline Stability Test & $17.84++$ & $20.06+++$ & $14.01+$ & $13.54+$ & 13.09 & 13.64 \\
\hline $\operatorname{coef}(L L)-\operatorname{coef}(R L)$ & & & & & $\begin{array}{c}0.2038^{* *} \\
(2.37)\end{array}$ & $\begin{array}{c}0.2076^{* *} \\
(2.41)\end{array}$ \\
\hline $\operatorname{coef}(L L)-\operatorname{coef}(L R)$ & & & & & $\begin{array}{c}0.4241 * * * \\
(8.85)\end{array}$ & $\begin{array}{c}0.4232 * * * \\
(8.71)\end{array}$ \\
\hline $\operatorname{coef}(R L)-\operatorname{coef}(L R)$ & & & & & $\begin{array}{c}0.2203 * * * \\
(2.74)\end{array}$ & $\begin{array}{c}0.2156^{* * *} \\
(2.68)\end{array}$ \\
\hline
\end{tabular}

Notes: $\quad * * *$ significant at $1 \%$ level, $* *$ at $5 \%, *$ at $10 \%$.

+++ null hypothesis rejected at $1 \%$ level, ++ at $5 \%,+$ at $10 \%$.

In parenthesis, t-statistic values (null hypothesis: value equal to zero).

The sample has 45 left-censored observations and 3 right-censored ones. 
Table 4. Factors explaining service-specific deficit level. Cities $>$ 5,000 inhabitants $(\mathrm{N}=95)$.

\begin{tabular}{|c|c|c|c|c|c|c|}
\hline Variable & Model 1 & Model 2 & Model 3 & Model 4 & Model 5 & Model 6 \\
\hline $\begin{array}{l}\text { Expenditure } \\
\text { Prediction Error }\end{array}$ & $\begin{array}{c}-0.4469 \\
(-1.22) \\
\end{array}$ & $\begin{array}{c}-0.4444 \\
(-1.22) \\
\end{array}$ & $\begin{array}{c}-0.2363 \\
(-0.87) \\
\end{array}$ & $\begin{array}{c}-0.2442 \\
(-0.88) \\
\end{array}$ & $\begin{array}{c}-0.3404 \\
(-1.25) \\
\end{array}$ & $\begin{array}{c}-0.3576 \\
(-1.30) \\
\end{array}$ \\
\hline Financial Difficulties & $\begin{array}{l}-.0019 \\
(-0.27)\end{array}$ & $\begin{array}{l}-0.0015 \\
(-0.22)\end{array}$ & $\begin{array}{l}0.0002 \\
(0.04)\end{array}$ & $\begin{array}{l}-0.0001 \\
(-0.02)\end{array}$ & $\begin{array}{l}0.0003 \\
(0.07)\end{array}$ & $\begin{array}{l}0.0001 \\
(0.07)\end{array}$ \\
\hline Private Production & $\begin{array}{r}-0.0609 \\
(-0.53) \\
\end{array}$ & $\begin{array}{c}-0.0446 \\
(-0.39) \\
\end{array}$ & $\begin{array}{r}-0.0349 \\
(-0.40) \\
\end{array}$ & $\begin{array}{r}-0.0459 \\
(-0.52) \\
\end{array}$ & $\begin{array}{c}-0.0212 \\
(-0.25) \\
\end{array}$ & $\begin{array}{c}-0.0265 \\
(-0.31) \\
\end{array}$ \\
\hline Leftist Mayor & $\begin{array}{c}0.2348 * * * \\
(3.42)\end{array}$ & $\begin{array}{c}0.2389 * * * \\
(3.54)\end{array}$ & & & & \\
\hline Leftist Constituency & & & $\begin{array}{c}0.4256^{* * *} \\
(8.93)\end{array}$ & $\begin{array}{c}0.4204 * * * \\
(8.61)\end{array}$ & & \\
\hline LeftM-LeftC (LL) & & & & & $\begin{array}{c}0.4984 * * * \\
(8.23) \\
\end{array}$ & $\begin{array}{c}0.5025 * * * \\
(8.22) \\
\end{array}$ \\
\hline LeftM-RightC (LR) & & & & & $\begin{array}{c}0.0860 \\
(1.44)\end{array}$ & $\begin{array}{c}0.0991^{*} \\
(1.66)\end{array}$ \\
\hline RightM-LeftC (RL) & & & & & $\begin{array}{c}0.3531 * * * \\
(3.47)\end{array}$ & $\begin{array}{c}0.3448 * * * \\
(3.35)\end{array}$ \\
\hline Minority & $\begin{array}{r}-0.0477 \\
(-0.39) \\
\end{array}$ & & $\begin{array}{c}0.1342 \\
(1.50) \\
\end{array}$ & & $\begin{array}{c}0.0959 \\
(1.06) \\
\end{array}$ & \\
\hline Roubini-Sachs & & $\begin{array}{c}-0.0473 \\
(-1.48) \\
\end{array}$ & & $\begin{array}{l}0.0071 \\
(0.29) \\
\end{array}$ & & $\begin{array}{l}-0.0005 \\
(-0.02) \\
\end{array}$ \\
\hline $\begin{array}{l}\text { Overall } \\
\text { Progressiveness }\end{array}$ & $\begin{array}{c}0.0034 \\
(0.99) \\
\end{array}$ & $\begin{array}{l}0.0031 \\
(0.92) \\
\end{array}$ & $\begin{array}{c}0.0047^{*} \\
(1.90) \\
\end{array}$ & $\begin{array}{c}0.0042^{*} \\
(1.67) \\
\end{array}$ & $\begin{array}{r}0.0029 \\
(1.05) \\
\end{array}$ & $\begin{array}{l}0.0023 \\
(0.84)\end{array}$ \\
\hline Constant & $\begin{array}{l}0.3920 \\
(0.77)\end{array}$ & $\begin{array}{l}0.4223 \\
(0.85) \\
\end{array}$ & $\begin{array}{l}0.0195 \\
(0.05) \\
\end{array}$ & $\begin{array}{c}0.0814 \\
(0.22) \\
\end{array}$ & $\begin{array}{c}0.1926 \\
(0.51) \\
\end{array}$ & $\begin{array}{l}0.2575 \\
(0.68) \\
\end{array}$ \\
\hline LR test full model & $16.71++$ & $18.75+++$ & $63.79+++$ & $61.69+++$ & $67.57+++$ & $66.47+++$ \\
\hline Pseudo R ${ }^{2}$ & 0.2064 & 0.2316 & 0.7880 & 0.7621 & 0.8348 & 0.8211 \\
\hline F regional dummies & 0.83 & 0.89 & 0.60 & 0.66 & 0.50 & 0.55 \\
\hline $\operatorname{coef}(L L)-\operatorname{coef}(R L)$ & & & & & $\begin{array}{r}0.1451 \\
(1.38) \\
\end{array}$ & $\begin{array}{r}0.1577 \\
(1.48) \\
\end{array}$ \\
\hline $\operatorname{coef}(L L)-\operatorname{coef}(L R)$ & & & & & $\begin{array}{c}0.4124 * * * \\
(7.20)\end{array}$ & $\begin{array}{c}0.4034^{* * * *} \\
(6.94)\end{array}$ \\
\hline $\operatorname{coef}(R L)-\operatorname{coef}(L R)$ & & & & & $\begin{array}{c}0.2672 * * * \\
(2.63)\end{array}$ & $\begin{array}{c}0.2457^{* *} \\
(2.41)\end{array}$ \\
\hline
\end{tabular}

Notes: $\quad * * *$ significant at $1 \%$ level, ${ }^{* *}$ at $5 \%,{ }^{*}$ at $10 \%$.

+++ null hypothesis rejected at $1 \%$ level, ++ at $5 \%,+$ at $10 \%$.

In parenthesis, $t$-statistic values (null hypothesis: value equal to zero).

The sample has 18 left-censored observations and 2 right-censored ones. 
Table 5. Factors explaining service-specific deficit level. Cities $<5,000$ inhabitants $(\mathrm{N}=75)$.

\begin{tabular}{|c|c|c|c|c|c|c|}
\hline Variable & Model 1 & Model 2 & Model 3 & Model 4 & Model 5 & Model 6 \\
\hline $\begin{array}{l}\text { Expenditure } \\
\text { Prediction Error }\end{array}$ & $\begin{array}{c}0.3611^{* *} \\
(2.17)\end{array}$ & $\begin{array}{c}0.3620^{* *} \\
(2.21)\end{array}$ & $\begin{array}{c}0.4245^{* * *} \\
(2.68) \\
\end{array}$ & $\begin{array}{c}0.4329 * * * \\
(2.78)\end{array}$ & $\begin{array}{c}0.3854^{* *} \\
(2.35) \\
\end{array}$ & $\begin{array}{c}0.3745^{* *} \\
(2.31) \\
\end{array}$ \\
\hline Financial Difficulties & $\begin{array}{l}-.0052 \\
(-1.11)\end{array}$ & $\begin{array}{c}-0.0054 \\
(-1.16) \\
\end{array}$ & $\begin{array}{c}-0.0041 \\
(-0.95)\end{array}$ & $\begin{array}{c}-0.0044 \\
(-1.02)\end{array}$ & $\begin{array}{c}-0.0039 \\
(-0.91)\end{array}$ & $\begin{array}{c}-0.0042 \\
(-0.99) \\
\end{array}$ \\
\hline Private Production & $\begin{array}{c}-0.1282^{* *} \\
(-2.62) \\
\end{array}$ & $\begin{array}{c}-0.1246^{* *} \\
(-2.54) \\
\end{array}$ & $\begin{array}{c}-0.1252 * * * \\
(-2.72) \\
\end{array}$ & $\begin{array}{c}-0.1202^{* *} \\
(-2.61)\end{array}$ & $\begin{array}{c}-0.1232 * * * \\
(-2.74)\end{array}$ & $\begin{array}{c}-0.1166^{* *} \\
(-2.58) \\
\end{array}$ \\
\hline Leftist Mayor & $\begin{array}{c}0.0661 \\
(1.48) \\
\end{array}$ & $\begin{array}{c}0.0598 \\
(1.29) \\
\end{array}$ & & & & \\
\hline Leftist Constituency & & & $\begin{array}{c}0.2519 * * * \\
(3.08)\end{array}$ & $\begin{array}{c}0.2520 * * * \\
(3.09)\end{array}$ & & \\
\hline LeftM-LeftC (LL) & & & & & $\begin{array}{c}0.3395^{* * * *} \\
(3.43) \\
\end{array}$ & $\begin{array}{c}0.3451 * * * \\
(3.48) \\
\end{array}$ \\
\hline LeftM-RightC (LR) & & & & & $\begin{array}{c}0.0371 \\
(0.85) \\
\end{array}$ & $\begin{array}{l}0.0221 \\
(0.48)\end{array}$ \\
\hline RightM-LeftC (RL) & & & & & $\begin{array}{l}0.1250 \\
(0.90)\end{array}$ & $\begin{array}{l}0.0935 \\
(0.65)\end{array}$ \\
\hline Minority & $\begin{array}{c}0.0156 \\
(0.14)\end{array}$ & & $\begin{array}{l}0.0417 \\
(0.41) \\
\end{array}$ & & $\begin{array}{l}0.0346 \\
(0.35)\end{array}$ & \\
\hline Roubini-Sachs & & $\begin{array}{c}0.0152 \\
(0.56)\end{array}$ & & $\begin{array}{c}0.0246 \\
(1.01)\end{array}$ & & $\begin{array}{l}0.0271 \\
(1.03)\end{array}$ \\
\hline $\begin{array}{l}\text { Overall } \\
\text { Progressiveness }\end{array}$ & $\begin{array}{l}0.0019 \\
(1.04)\end{array}$ & $\begin{array}{c}0.0019 \\
(1.01)\end{array}$ & $\begin{array}{c}0.0010 \\
(0.58) \\
\end{array}$ & $\begin{array}{l}0.0010 \\
(0.57) \\
\end{array}$ & $\begin{array}{c}0.0012 \\
(0.69) \\
\end{array}$ & $\begin{array}{l}0.0011 \\
(0.62)\end{array}$ \\
\hline Constant & $\begin{array}{l}-0.3530 \\
(-1.53)\end{array}$ & $\begin{array}{l}-0.3556 \\
(-1.56)\end{array}$ & $\begin{array}{c}-0.3676^{*} \\
(-1.71) \\
\end{array}$ & $\begin{array}{c}-0.3869^{*} \\
(-1.82)\end{array}$ & $\begin{array}{c}-0.3521 \\
(-1.57) \\
\end{array}$ & $\begin{array}{c}-0.3411 \\
(-1.55)\end{array}$ \\
\hline LR test full model & $15.95++$ & $16.25++$ & $22.64+++$ & $23.49+++$ & $25.16+++$ & $26.12+++$ \\
\hline Pseudo R ${ }^{2}$ & 0.5406 & 0.5507 & 0.7673 & 0.7961 & 0.8528 & 0.8855 \\
\hline F regional dummies & 0.29 & 0.29 & 0.45 & 0.45 & 0.32 & 0.28 \\
\hline $\operatorname{coef}(L L)-\operatorname{coef}(R L)$ & & & & & $\begin{array}{c}0.2146 \\
(1.30) \\
\end{array}$ & $\begin{array}{c}0.2516 \\
(1.47) \\
\end{array}$ \\
\hline $\operatorname{coef}(L L)-\operatorname{coef}(L R)$ & & & & & $\begin{array}{c}0.3025^{* * * *} \\
(2.98)\end{array}$ & $\begin{array}{c}0.3230 * * * \\
(3.12)\end{array}$ \\
\hline $\operatorname{coef}(R L)-\operatorname{coef}(L R)$ & & & & & $\begin{array}{c}0.0879 \\
(0.64) \\
\end{array}$ & $\begin{array}{c}0.0714 \\
(0.51) \\
\end{array}$ \\
\hline
\end{tabular}

Notes: $\quad * * *$ significant at $1 \%$ level, $* *$ at $5 \%, *$ at $10 \%$.

+++ null hypothesis rejected at $1 \%$ level, ++ at $5 \%,+$ at $10 \%$.

In parenthesis, t-statistic values (null hypothesis: value equal to zero).

The sample has 27 left-censored observations and 1 right-censored one. 